\title{
Braendeovne på godt og ondt - ikke kun oliepriserne, der ryger $i$ vejret
}

Af cand.scient. Thommy Larsen, Institut for Miljøvurdering

Prøv at lytte godt efter næste gang, du tænder op i din brændeovn. Det, du sandsynligvis vil kunne høre, er din nabo, der hoster. Røgen fra brændeovnene er nemlig ved at forvandle rolige parcelhuskvarterer til områder, der er så plagede af luftforurening, at selv de mest befærdede veje i København har svært ved at følge med. Selvom der endnu ikke er sikkerhed om helbredseffekterne peger flere ting på, at røgen ikke er ufarlig - langt fra.

Vi er nu midt på efteråret og nærmer os vinteren. Det betyder, at kulde, regn og blæst får os til at rykke indenfor og skrue lidt ekstra op for varmen. I énfamiliehuse er det $\mathrm{i}$ løbet af de senere år blevet populært at anskaffe sig en brændeovn. Det vides ikke præcist, hvor mange hjem der har en brændeovn stående, men det anslås, at der i 2004 er ca. 700.000 brændeovne i Danmark. Det svarer til, at knap halvdelen af alle danske énfamiliehuse har brændeovn, som benyttes som supplement til den primære varmekilde, eller blot som hyggespreder. Det samme tal var i $1995 \mathrm{ca} .400 .000$.

Tendensen kan ligeledes ses i statistikken over, hvor meget træ der bliver produceret $i$ Danmark med det formål at blive anvendt som brænde. Således er produktionen steget med $30 \%$ fra 1990 til 2002. Umiddelbart er det forståeligt nok, at danskerne ønsker at

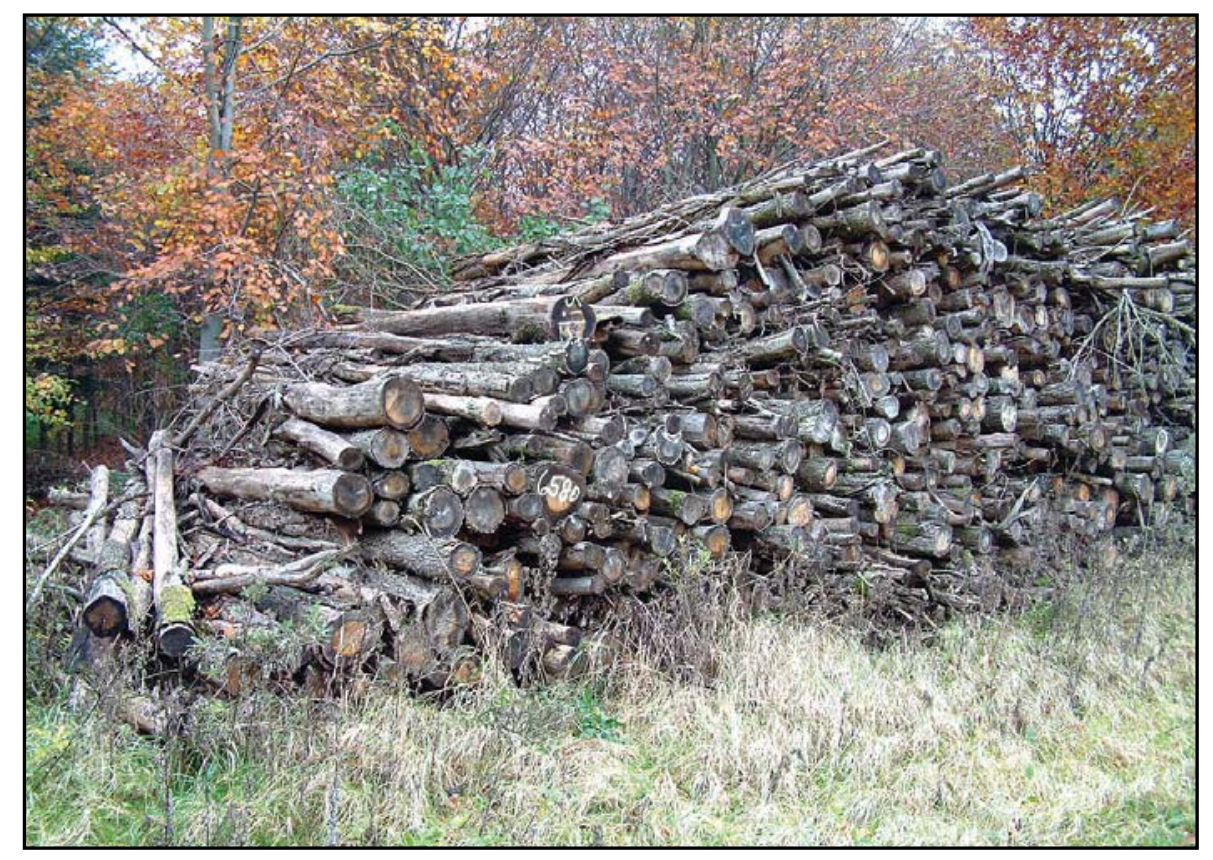

Naste års brande ligger parat ude i skoven. Det skal bare kløves og lagges til tørring. (Foto: Forfatteren)

skifte olien eller naturgassen ud med træ. I skrivende stund er prisen på 1.000 liter fyringsolie $7.243 \mathrm{kr}$. Brændværdien af 2 tons tørt bøge-, ege- eller birketræ svarer stort set til 1.000 liter fyringsolie, men koster kun omkring $3.000 \mathrm{kr}$. Dvs. at husejeren vil kunne spare ca. $4 \mathrm{kr}$. pr. liter olie, der fortrænges til fordel for brænde. Denne simple beregning skal dog ikke tages alt for bogstaveligt, da typen af brændeovn, placering mv. spiller ind i det endelige regnskab. Derudover varierer prisen på brænde og olie også. Men at der er penge at spare, er der ingen tvivlom.
Hvor meget forurener en brændeovn? De fleste tænker nok på en træfyret brændeovn som en miljørigtig energikilde, primært fordi træ jo som bekendt er et naturprodukt. Det er da også rigtigt, at fyring med træ er $\mathrm{CO}_{2}$-neutral forstået på den måde, at den $\mathrm{CO}_{2}$, der frigøres ved forbrænding, er blevet bundet i træet gennem dets levetid. Den miljømæssige gevinst består i en reduceret drivhuseffekt, vel at mærke hvis brugen af brændeovnen giver et reduceret gas- eller olieforbrug. Derimod har brændeovne en negativ miljømæssig effekt på lokalområdet. Danmarks Miljøundersøgelser er i gang med 


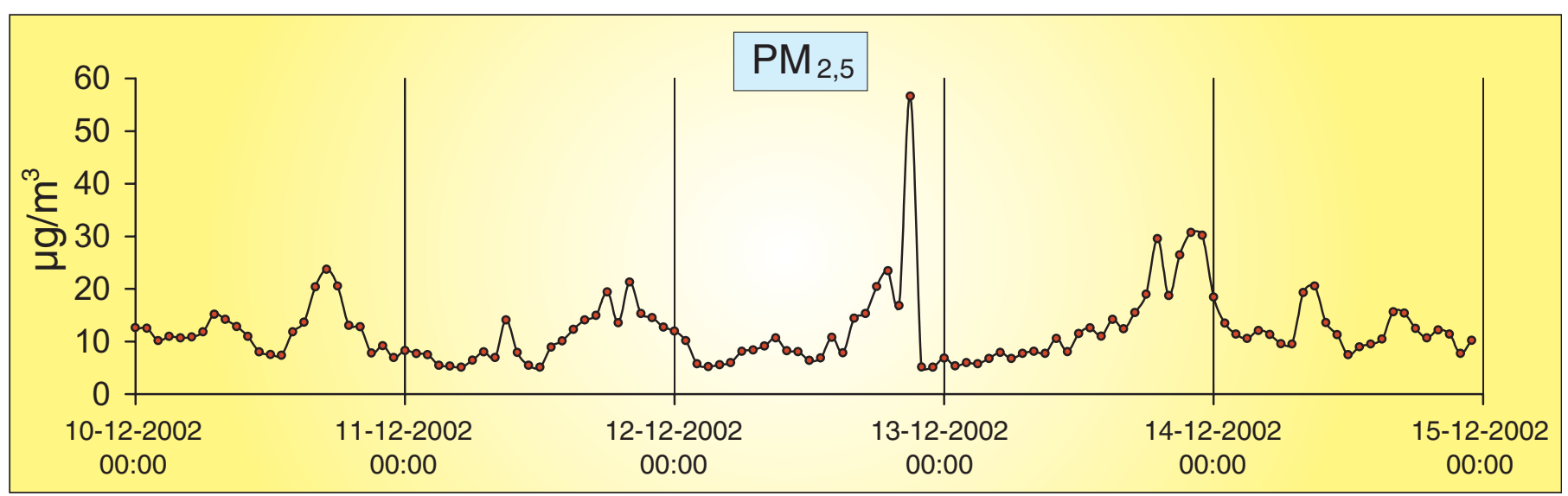

Luftens indhold af partikelmasse (PM, ${ }_{2}$ ) som timemiddelvardier angivet $i \mu g / m^{3}$. Målingerne er foretaget $i$ et rakkehusområde med mange brandeovne $i$ en vinterperiode med koldt og vindstille vejr, hvor udledningerne fortyndes langsomt. Til sammenligning har partikelkoncentrationerne på H.C. Andersens Boulevard i oktober 2004 varieret mellem $5 \mathrm{og} 39 \mu \mathrm{g} / \mathrm{m}^{3}$ (lavest om natten og højest i myldretiden). (Grafik: UVH modificeret efter Wåhlin et al. (2003))

at undersøge, hvor høj luftforureningen er i villa- og parcelhusområder, og hvor meget der stammer fra brændeovne. De foreløbige resultater viser, at koncentrationen af fine partikler (partikler som har en diameter mindre end 2,5 mikrometer) på kolde, vindstille aftener er lige så høj i et rækkehusområde som på H.C. Andersens Boulevard i København midt i myldretiden. For at sætte det lidt i perspektiv, bør det nævnes, at luftforureningen ved H.C. Andersens Boulevard, som er en af de mest trafikerede veje i København, jævnligt overskrider EU's grænseværdier, både hvad angår partikler og kvælstofilter. Målingerne for rækkehusområdet er vist i grafen. Døgnvariationen er tydelig, idet partikelkoncentrationen topper om aftenen. Den meget markante top om aftenen d. 12. december skyldes formentlig en særlig vindstille aften.

Den samlede udledning af fine partikler fra danske brændeovne er stadig kun kendt med stor usikkerhed. Tallet er tidligere blevet anslået til at udgøre $13 \%$ af den samlede udledning svarende til 1.600 tons pr. år, men de nyeste tal kunne indikere, at det er væsentligt højere.

I faktaboksen er der vist nogle af de kemiske forbindelser, der indgår i røgen fra afbrænding afbirketræ. Samtidigt er mængden angivet som mg pr. kg afbrændt birketræ (dog antal partikler pr. $\mathrm{kg}$ for ultrafine partiklers vedkommende). Tallene stammer fra en svensk undersøgelse, som er blevet publiceret i fagtidsskriftet Atmospheric Environment. Emissionsmålingerne er foretaget ved at fyre en typisk brændeovn op med tørt birketræ og måle røggasens sammensætning umiddelbart efter brændeovnens tilslutning til skorstenen. Der blev jævnligt lagt nyt træ i ovnen for at simulere den typiske anvendelse. Faktaboksen medtager kun de stoffer, der blev målt de største mængder af. Det skal lige nævnes, at der er tale om gennemsnitsværdier, da de målte værdier kunne variere med flere størrelsesordener. Det illustrerer samtidigt, at forbrændingen i en brændeovn ikke forløber jævnt, men varierer, afhængigt af hvor meget træet er brændt igennem, hvor meget ilt der er tilstede osv. Det skal også siges, at der er lavet tilsvarende undersøgelser for andre træsorter, som giver tilsvarende resultater.

\section{Hvordan kan rogen påvirke helbredet?} Lad det være sagt med det samme: Vi har ikke noget samlet overblik over brænderøgens indvirkning på helbredet. Man kan få et hint over farligheden ved at se på emissionerne fra en typisk brændeovn, som det er gjort i faktaboksen.

Det, der måske er overraskende for mange, er, at listen indeholder mange stoffer, som er kendt for at være kræftfremkaldende, hormonforstyrrende eller "blot" åndedræts- forstyrrende. Tjærestoffet Benzo(a)pyren er således kendt for at være kræftfremkaldende, give arvelige genetiske skader samt svække reproduktionsevnen. Det samme er gældende for Flouranthen, om end giftigheden vurderes til at være $5 \%$ af Benzo(a)pyren ifølge den svenske undersøgelse. Alligevel er effekten væsentlig, fordi de udledte mængder af Flouranthen kan ses at være omkring 8 gange større end af Benzo(a)pyren.

Aldehyderne optræder i ret store mængder i røggassen. Indånding af aldehyder er kendt for at give åndedrætsbesvær og irritationer af øjne og næse. Det stemmer godt overens med de gener, der berettes om af naboerne til brændeovnene.

\begin{tabular}{|c|c|}
\hline \multicolumn{2}{|c|}{ Emissioner fra brændeovne ved afbrænding af birketræ } \\
\hline $\begin{array}{c}\text { Kemisk } \\
\text { forbindelse }\end{array}$ & $\begin{array}{l}\text { Udledte mængder pr. kg } \\
\text { afbrændt birketræ (mg) }\end{array}$ \\
\hline \multicolumn{2}{|c|}{$\begin{array}{l}\text { Aldehyder og Ketoner (forskellige forbindelser, } \\
\text { der indeholder kulstof-oxygen-bindinger) }\end{array}$} \\
\hline $\begin{array}{l}\text { Formaldehyd } \\
\text { Acetone } \\
\text { Acetaldehyd }\end{array}$ & $\begin{array}{l}422 \\
366 \\
86,3\end{array}$ \\
\hline \multicolumn{2}{|l|}{$\begin{array}{l}\text { BTEX (forkortelse for Benzen, Toluen, } \\
\text { Ethylbenzen, Xylen) }\end{array}$} \\
\hline $\begin{array}{l}\text { Benzen } \\
\text { Toluen } \\
\text { p-Xylen }\end{array}$ & $\begin{array}{l}1.500 \\
740 \\
100\end{array}$ \\
\hline \multicolumn{2}{|l|}{ PAH (tjærestoffer) } \\
\hline $\begin{array}{l}\text { Fluoren } \\
\text { Phenanthren } \\
\text { Anthracen } \\
\text { Fluoranthen } \\
\text { Pyren } \\
\text { 2-Phenylnaphtalen } \\
\text { Benz(a)fluoren } \\
\text { Benzo(b)fluoranthen } \\
\text { Benzo(a)pyren }\end{array}$ & $\begin{array}{c}27,4 \\
99,1 \\
19,3 \\
29,4 \\
25,5 \\
6,3 \\
5,2 \\
6,1 \\
3,6\end{array}$ \\
\hline \multicolumn{2}{|l|}{ Partikler } \\
\hline $\begin{array}{l}\text { Fine (diameter mindre end } 2,5 \mu \mathrm{m} \text { ) } \\
\text { Ultrafine(diameter mindre end } 0,1 \mu \mathrm{m} \text { ) }\end{array}$ & $\begin{array}{c}1.300 \\
<4 \times 10^{14} \text { partikler pr. kg afbrændt træ }\end{array}$ \\
\hline
\end{tabular}

Faktaboksen viser de kemiske forbindelser, der findes i røg fra afbrcending af birketra. (Grafik: UVH modificeret efter Hedberg et al. (2002)) 


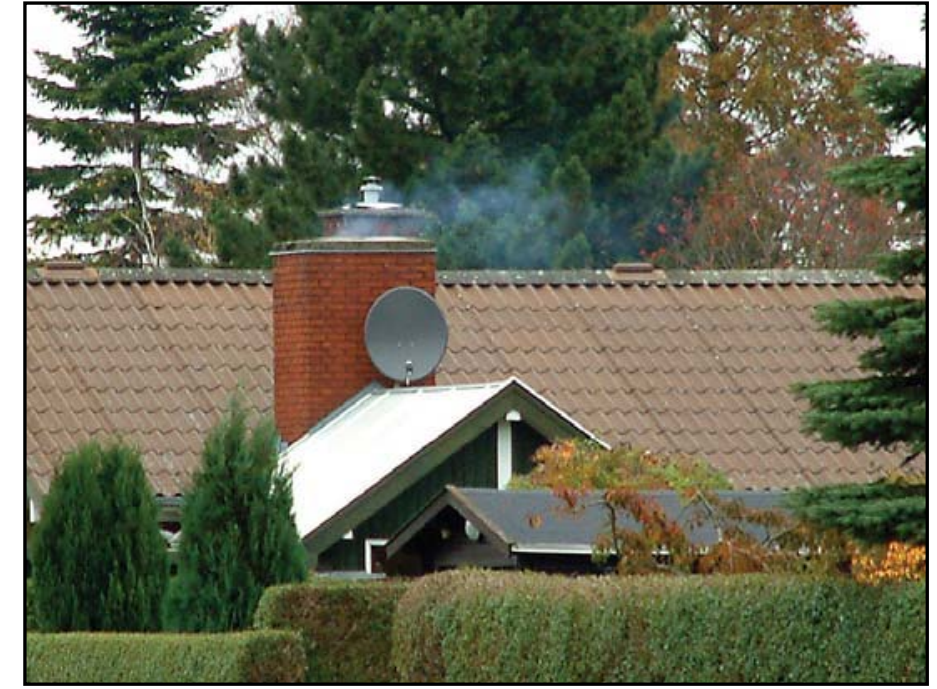

Typisk brcendeovnsmiljø: Parcelhus, lav skorsten og høje trceer omkring huset. Bemork, at røgen holder sig nede i hushøjde. (Foto: Forfatteren)

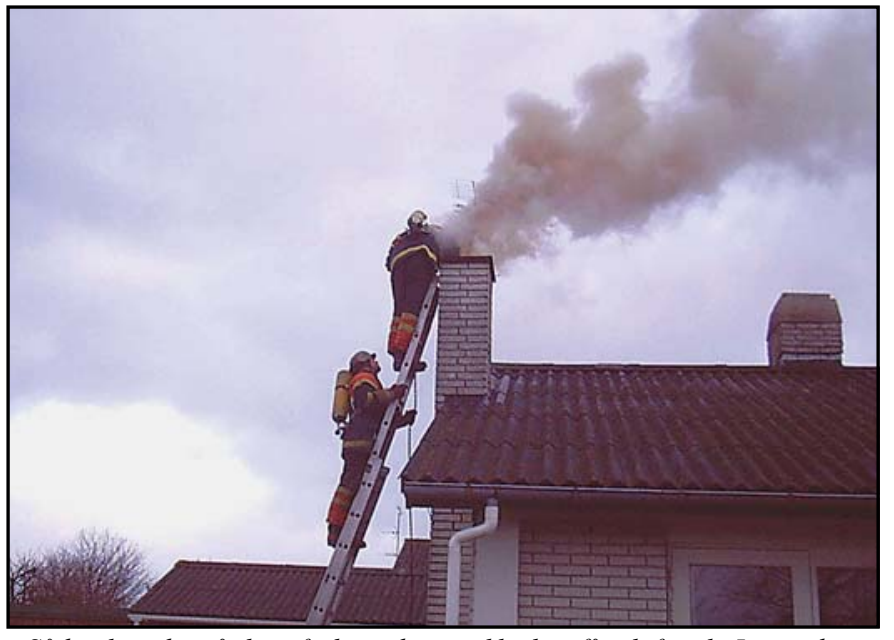

Sådan kan det gå, hvis forbrandingen ikke har fået luft nok. Langt de fleste skorstensbrande skyldes brandeovne, der enten er blevet opfyret med for vådt trae, eller har fået tilført for lidt luft, og dermed danner løbesod i skorstenen. (Foto: Beredskabet Vallø-Stevns)
Noget af det, der har været diskuteret meget $\mathrm{i}$ forbindelse med sammenhængen mellem partikler og helbred, er, hvilke partikelstørrelser, der er de farligste. Vores nuværende viden bygger i høj grad på nogle amerikanske kohortestudier (undersøgelser hvor en gruppe personer følges gennem flere år for at sammenholde partikelkoncentrationer med sygdom og dødsfald) for fine partikler, hvorimod der for ultrafine partikler (diameter mindre end $0,1 \mu \mathrm{m}$ ) kun er undersøgelser af akutte effekter. Imidlertid er der fremkommet en lang række indicier på, at deres indflydelse på helbredet er væsentlig større, end det er tilfældet for fine partikler. Årsagen til dette er, at ultrafine partikler kan trænge længere ud i lungerne og herfra blive optaget i blodet. Ved længere tids eksponering for fine partikler og altså formodentlig også for ultrafine partikler stiger risikoen for at få hjerte-karsygdomme, kræft og kronisk bronkitis - hvoraf de to førstnævnte ofte fører til dødsfald.

Den svenske undersøgelse har set på størrelsesfordelingen af de partikler, der findes i røggasen fra birkebrændet. De fleste partikler har en størrelse på 0,02-0,3 $\mu \mathrm{m}$ med et maksimum ved $0,05 \mu \mathrm{m}$. En meget stor del af partiklerne er altså ultrafine. Hvis denne størrelse partikler er så farlige, som de er mistænkt for at være, kan der her være en væsentlig helbredsrisiko for de menne-

sker, der bor tæt på et hus med brændeovn. Faktisk er der også en risiko for brændeovnsejeren selv, dels fordi ultrafine partikler er i stand til at trænge ind $i$ huset gennem murværket, dels fordi der også kan være tale om et direkte udslip fra selv tætte brændeovne (og selvfølgelig langt større for pejse).

Vi har nu set, at de bestanddele, røgen er bygget op af, hver især er mere eller mindre sundhedsskadelige. Kan man bruge denne viden til at estimere de helbredsmæssige risici, der er ved at bo i et område med mange brændeovne? Umiddelbart ikke. Det, der har betydning for vores helbred, er stofkoncentrationerne i den luft, vi indånder. Emissionerne fra skorstenene blandes sammen med den omgivende luft, hvorved røggassen fortyndes. Jo længere væk fra kilden man befinder sig, jo mindre vil emissionerne betyde for den samlede koncentration i luften. Bygningerne i parcelhus- og villakvarterer ligger tæt på hinanden, og skorstenene er forholdsvis lave. Det betyder, at røgen ikke når at blive fortyndet ret meget, før mennesker udsættes for den. Det taler for store helbredsmæssige risici. Til gengæld forekommer forureningen kun i fyringssæsonen, hvilket reducerer risikoen for udvikling af kroniske sygdomme.

Det er formentlig ikke kun størrelsen af partiklerne, der betyder noget for deres farlighed, men også deres sammensætning. De ovennævnte undersøgelser af sammenhængen mellem partikler og helbred tager alle udgangspunkt i dieselpartikler, som har en noget anderledes sammensætning end partikler fra afbrænding af træ. Målinger af tjærestofindholdet i partikler i villakvarterer hhv. stærkt befærdede veje viser, at "villapartiklerne" i fyringssæsonen har det klart højeste tjærestofindhold. Dette kan tjene som en indikation af, at partiklerne fra brændeovnene ikke er mindre farlige, hvad angår kræftrisiko, men det er ikke muligt at slutte noget endeligt ud fra dette.

Selvom vi har at gøre med en af de største kilder til partikelforureningen i Danmark, har den komplekse problemstilling kombineret med hidtil manglende opmærksomhed på problemet betydet, at det endnu ikke er muligt at vurdere, hvor mange kræfttilfælde, hjerte-karsygdomme og andre sygdomme/gener der kan tilskrives røgen fra brændeovnene.

\section{Hvad kan man gøre?}

$\mathrm{Nu}$ sidder den, efter at have læst denne artikel, ulykkelige brændeovnsejer nok og overvejer, hvad han kan gøre. På længere sigt er der hjælp på vej. Filtre til montering på skorstensrøret bliver produceret, men er endnu meget dyre, hvis de da er til at få fat i. Indtil da er der nogle gode råd, man kan følge. Grundlæggende gælder det om at opnå en så høj forbrændingstemperatur som muligt. Derfor gælder det om kun at fyre med tørt træ. Som grundregel skal brændet være fældet vinteren før den aktuelle fyringssæson, så det har tørret sommeren over. Tænd op med kvas og småkviste, og kun meget lidt avispapir, da tryksværten kan give anledning til dannelsen af dioxin. Dioxin er stærkt kræftfremkaldende og hormonforstyrrende. Brug aldrig affaldstræ (paller, det gamle hegn eller lignende), mælkekartoner eller andet affald. For det første bliver udledningerne af de stoffer der er nævnt $i$ faktaboksen større. For det andet vil der også udvikles dioxin, og for det tredje er det ulovligt for private husstande at afbrænde affald. Herudover er der også risiko for, at der dannes løbesod i skorstenen som på et eller andet tidspunkt vil føre til en skorstensbrand. Sørg også for at der er rigeligt med luft til forbrændingen, hvilket sikrer en høj temperatur og dermed en mere ren røggas.

Hvis disse råd følges vil de helbredsmæssige effekter af brændeovnene blive minimeret, men ikke elimineret. Yderligere undersøgelser skal gennemføres for at give et mere veldefineret billede af effekterne. Derefter må en politisk beslutning afgøre, om der skal skrides ind, og hvordan det evt. kan gøres mest hensigtsmæssigt.

\section{Litteratur:}

Glasius, M., Wåhlin, P. \& Palmgren, F.: Brcendeovne forurener luften, DMU-nyt 8 årgang, nr. 6, 2004 (kan loeses på $w w w . d m u . d k$ )

Hedberg, E., Kristensson, A., Ohlsson, M., Johansson, C., Johansson, P.-A., Swietlicki, E., Vesely, V., Wideqvist, U., Westerholm, R., Atmospheric Environment $36,4823,2002$

Wåhlin, P., Mønster, J.G., Glasius, M., Ketzel, M., Berkowicz, R. \& Palmgren, $F .:$ Measurements of wood burning emissions in Denmark - first results. Poster og abstract prcesenteret ved NOSA 2003 Aerosol Symposium, København, Danmark, 13.-14. november 2003. 